\title{
DÜBLIN
}

Technological University Dublin

ARROW@TU Dublin

2008-01-01

\section{A Metal Plate Solar Antenna for UMTS Pico-cell Base Station}

\author{
S. Shynu \\ Technological University Dublin \\ Maria Roo Ons \\ Technological University Dublin \\ Max Ammann \\ Technological University Dublin, max.ammann@tudublin.ie
}

See next page for additional authors

Follow this and additional works at: https://arrow.tudublin.ie/engschececon

\section{Recommended Citation}

Shynu, S. et al. (2008) A metal plate solar antenna for umts pico-cell base station. LAPC 2008: Antennas and Propagation Conference, pp.373-376. Loughborough, 17-18 March, 2008, doi:10.1109/

LAPC.2008.4516944

This Conference Paper is brought to you for free and open access by the School of Electrical and Electronic Engineering at ARROW@TU Dublin. It has been accepted for inclusion in Conference papers by an authorized administrator of ARROW@TU Dublin. For more information, please contact arrow.admin@tudublin.ie, aisling.coyne@tudublin.ie,gerard.connolly@tudublin.ie.






\section{Authors}

S. Shynu, Maria Roo Ons, Max Ammann, Sarah McCormack, and Brian Norton 


\title{
A METAL PLATE SOLAR ANTENNA FOR UMTS PICO-CELL BASE STATION
}

\author{
Shynu S. V ${ }^{1}$, Maria J. Roo Ons ${ }^{1}$, Max J. Ammann ${ }^{1}$, Sarah McCormack ${ }^{2}$ and Brian \\ Norton ${ }^{2}$ \\ ${ }^{1}$ School of Electronic and Communications Engineering, \\ Dublin Institute of Technology, Dublin, Ireland \\ ${ }^{2}$ Dublin Energy Lab, Focas Institute, Dublin, Ireland
}

\section{Introduction}

Recently, communication systems integrated with photovoltaic technology for low cost and stand alone applications received much interest. The photovoltaic systems of power generation when combined with communications systems can provide compact and reliable autonomous communication systems for many applications [1-2]. A stand alone remote base station is one such application where PV technology can be used. But these devices often involve the use of separate solar cells and antennas, which necessitate a compromise in the utilization of the limited surface available. Integrating the base station antennas into photovoltaic solar cells can provide compact and reliable solution. A combination of microstrip antenna and solar cell in one device for GPS applications is recently been proposed [3]. Here we propose a novel design of metal plate solar antenna for low cost UMTS base station applications. The radiating element used is a quarter wave length shorted metal plate with air substrate. In most of the reported solar antenna designs, the radiating element above the solar cell obstructs the incidence light and thereby reducing the solar cell efficiency. Therefore a reduced size patch antenna is always desirable for the integration. Shorted patch antennas with shorting walls are quarter wavelength structures and thus suitable for integration with solar cells [4].

\section{Solar antenna design}

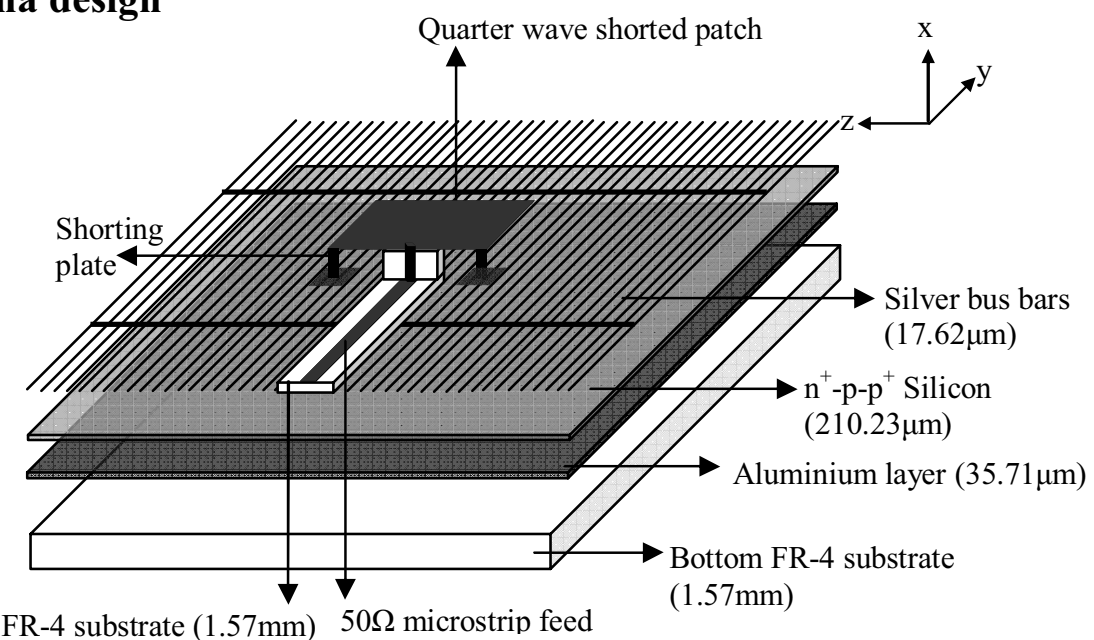

Figure 1 Exploded layout of the proposed shorted patch over the solar cell

The geometry of the proposed metal plate solar antenna for UMTS base station is shown in Figure 1. To achieve total integration of the solar cell and the antenna, high efficiency polycrystalline silicon solar cells of dimension 15.6 × 15.6 x $0.026 \mathrm{~cm}$ developed by Solland were used as the ground plane for the metal plate antenna and its microstrip feed system. The solar cell consists of an aluminium back contact layer of thickness $35.71 \mu \mathrm{m}$ and silicon $\mathrm{n}^{+}-\mathrm{p}-\mathrm{p}^{+}$layer with a thickness of $210.23 \mu \mathrm{m}$. The silver bus bars for DC collection have a thickness of $17.62 \mu \mathrm{m}$ giving an overall solar cell thickness of 
$0.026 \mathrm{~cm}$. The radiating patch used is a $0.2 \mathrm{~mm}$ thickness copper metal sheet with a length $L$ and width $W$. The radiating patch is placed $h$ above the ground and shorted to the silver grids of the solar cell using two shorting metal posts as in Figure 1. The feeding mechanism employed is a $50 \Omega$ microstrip line with solar cell as RF ground plane. By suitably adjusting the width, $w_{s}$ of the two shorting metal plates, good impedance matching of the antenna can be achieved. The height of the patch, $h$ above the silver bus bars determines the available bandwidth for UMTS band. The maximum initial electrical conductivity of the cell in dark state is $380.8 \mathrm{Sm}^{-1}$ which will vary with incident photon flux density. Standard conductivity values are used for $A l$ and $A g$ for the simulation purpose.

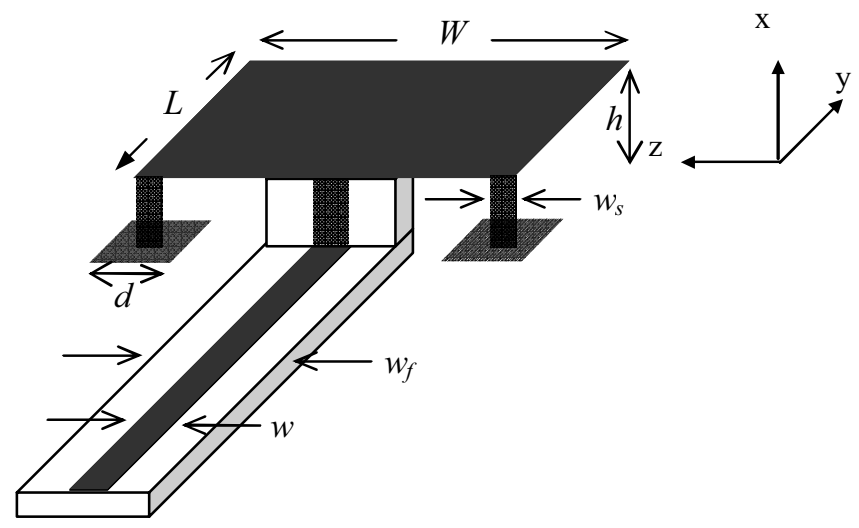

Figure 2 Various dimension of the shorted patch and microstrip feed line. $L=22 \mathrm{~mm}, W=50 \mathrm{~mm}, h=10 \mathrm{~mm}, d=6.56 \mathrm{~mm}, w=3 \mathrm{~mm}, w_{f}=$ $10 \mathrm{~mm}, w_{s}=1 \mathrm{~mm}, \epsilon_{r}=4.3$ and $\tan \delta=0.015$

For the proposed UMTS base station antenna application, the design parameters used are, $L=22 \mathrm{~mm}$, $W=50 \mathrm{~mm}, h=10 \mathrm{~mm}, d=6.56 \mathrm{~mm}, w=3 \mathrm{~mm}, w_{f}=10 \mathrm{~mm}, w_{s}=1 \mathrm{~mm}, \epsilon_{r}=4.3, \tan \delta=0.015$ and substrate height $h_{1}=1.57 \mathrm{~mm}$. For better ground connection, two small metal patches of length $d$ are used to fix the shorting plates with thin silver bars of the solar cell. The detailed dimension of the patch is given in Figure 2.

The desired orientation of the silver bus bars is along the y-axis, parallel to the resultant electric field in the shorted patch. Two prototypes were studied with the Ag-bus bars are orienting along y-axis (Ag-parallel) and along z-axis (Ag-perpendicular) in order to compare the difference in the antenna performance. Since both the microstrip feed and the shorted patch are using the solar cell as the RF ground plane, the orientation of the Ag bus bars can affect the solar antenna performance.

\section{Results and discussion}

The simulated $\mathrm{S}_{11}$ for the proposed solar antenna is given in Figure 3. A comparison is made with the ideal shorted patch antenna with PEC ground. A wide impedance bandwidth of $16.6 \%$ in the UMTS band is achieved with the Ag-parallel design. A comparison of the antenna parameters are shown in Table 1. Good broad side radiation patterns are obtained for the solar antenna (Figure 4). However, the H-plane radiation patterns shows a higher level of cross polarisation as observed in other shorted patch antenna designs. Even though no substantial difference in gain and radiation pattern is observed for the two different Ag-bus bar orientations, the return loss characteristics and bandwidth are different. The analysis of the surface currents in the Ag-grids for the two designs is given in Figure 5. From the current distribution in Fig. 5 (b), we can see that higher reflection of the surface currents occurs in the Ag grid, when it is oriented in 'perpendicular' (z-direction) to the direction of the surface current flow (towards y-axis) in the grids. Surface currents in the Ag-grids beneath the microstrip feed line and the patch needs an even PEC 'surface' for the propagation. The ideal patch, surface currents in the ground plane are undisturbed towards the propagation direction (y-axis). In the solar antenna design, the Aglines of the solar cell with a height of $17.6 \mu \mathrm{m}$ (in z-direction) when oriented in the 'perpendicular' 
direction (z-axis) can cause major reflections for the y-directed ground currents and hence the poor return loss performance [5].

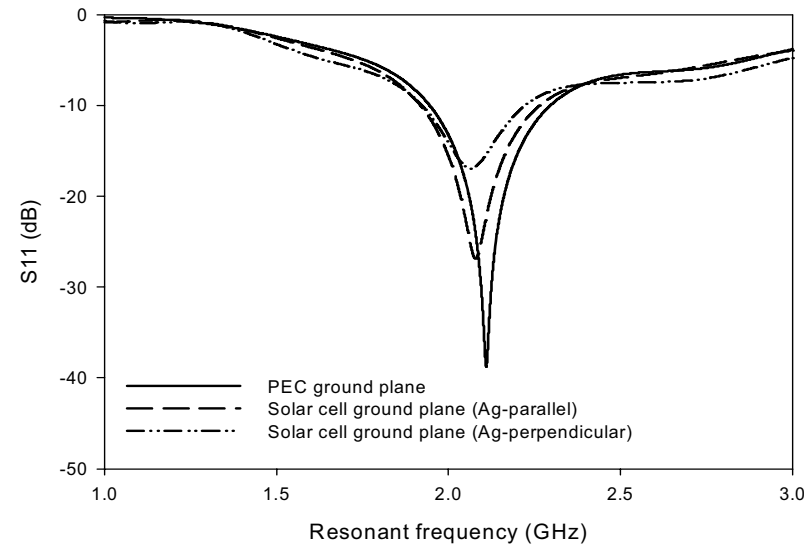

Figure 3 Simulated $\mathrm{S}_{11}$ of the two different Ag-bus bar orientations of solar antenna compared to an ideal shorted patch with PEC ground plane

Table 1. Summary of simulated results

\begin{tabular}{cccc}
\hline UMTS antenna type & $\begin{array}{c}\text { Resonant } \\
\text { frequency } \\
(\mathrm{GHz})\end{array}$ & \% Bandwidth & Gain (dBi) \\
\hline $\begin{array}{c}\text { Solar antenna (Ag- } \\
\text { parallel) }\end{array}$ & 2.0800 & 16.6 & 3.9 \\
$\begin{array}{c}\text { Solar antenna (Ag- } \\
\text { perpendicular) }\end{array}$ & 2.0640 & 14.5 & 4.0 \\
Ideal PEC ground plane & 2.1088 & 16.6 & 3.9 \\
\hline
\end{tabular}

For Ag-parallel orientation of the solar antenna, the orientation of the Ag-lines is along the direction of the ground currents (towards y-axis). Therefore the ground currents in the Ag-grids for Ag-parallel orientation experience negligible reflection. However, the two major silver bus bars (see Fig. 1) are orthogonal to the y-direction and cause minor reflections and thus degrade the return loss performance.

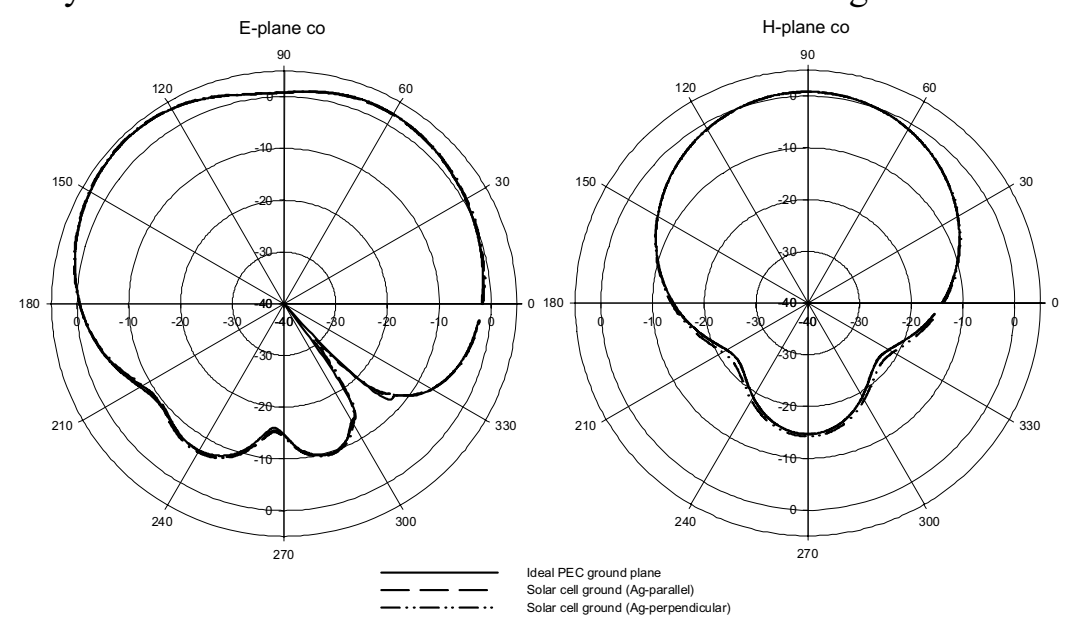

Figure 4 E-plane (x-y) and H-plane (x-z) co-polar radiation patterns for the proposed solar antenna

For the Ag-perpendicular case, the higher input reactance $(12.6 \Omega)$ suggests that higher returned energy is coming into the source because of the reflection from the perpendicularly oriented Ag-lines. 
This leads to poor return loss performance for Ag-perpendicular design. For the Ag-parallel solar antenna design the input reactance is only $4 \Omega$ and that for the ideal patch its $1.2 \Omega$.

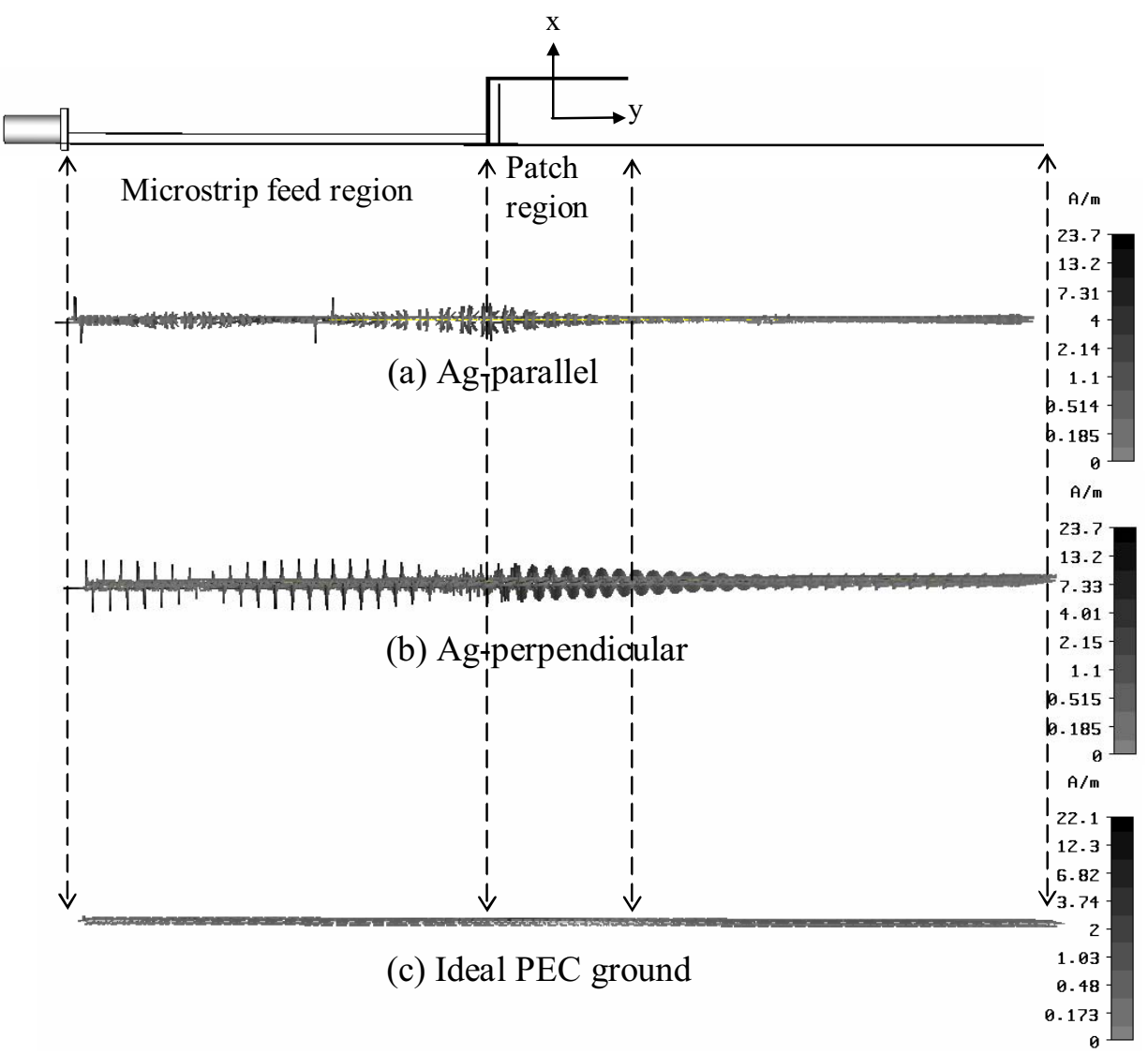

Figure 5 Cross sectional view of surface currents in the solar cell silver bus bars and ideal PEC ground plane

\section{Conclusion}

A simple low-cost solar antenna design for UMTS base station is proposed. The optimum orientation of the silver DC bus bars of the solar cell is found to be Ag-parallel, in order to achieve best antenna performance. Good antenna performance similar to that of ordinary shorted patch antennas is obtained.

\section{References}

[1] S. Vaccaro, J. R. Mosig and P. Maagt, "Two Advanced Solar Antenna SOLANT Designs for Satellite and Terrestrial Communications", IEEE Trans. Antennas and Propagation, vol-51, no-8, page- 2028-2034, 2000.

[2] S.V Shynu, M. J. Roo Ons, M.J Ammann, S. McCormack and B. Norton, "Inset fed Microstrip Patch Antenna with Integrated Polycrystalline Photovoltaic Solar Cell", European Conference on Antennas and Propagation, EUCAP-2007, Edinburgh, 2007

[3] N. Henze, M. Weitz, P. Hofmann, C. Bendel, J. Kirchoff and H. Fruchting, "Investigations on Planar Antennas with Photovoltaic Solar Cells for Mobile Communications", IEEE International Symposium on Personal, Indoor and Mobile Radio Communications, (PIMRC) vol-1, page- 622626, 2004

[4] K.L Wong, "Planar Antennas for Wireless Communications Systems," John Wiley \& Sons, New Jersey, pp. 127-193,

[5] C.A Grimes, J.L Horn, F. Tefiku and R. Shahidain, "An Experimental Investigation into the Control of Antenna Input Impedance through Cancellation of Near Field Standing Energy", Proceedings of IEEE Aerospace Conference 1998, vol-3, pp. 273-282 